\title{
Groundwater flow modelling of Yamuna-Krishni interstream, a part of central Ganga Plain Uttar Pradesh
}

\author{
IzRAR Ahmed and RASHid UmaR* \\ Department of Geology, Aligarh Muslim University, Aligarh 202 002, India. \\ *e-mail: rashidumar@rediffmail.com
}

\begin{abstract}
Groundwater is a major source of water for agricultural and domestic requirements in western Uttar Pradesh. Due to increasing agricultural requirements the abstraction of groundwater has increased manifold in the last two-to-three decades. The quaternary alluvium hosts the aquifer in the region. The study area forms a part of Yamuna-Krishni interfluve. Although the area hosts potential aquifers these have been adversely affected by poor management. For effective groundwater management of a basin it is essential that a careful water balance study should be carried out. Keeping this in mind groundwater flow modelling was attempted to simulate the behaviour of the flow system and evaluate the water balance. The groundwater flow modelling was carried out. The horizontal flows, seepage losses from unlined canals, recharge from rainfall and irrigation return flows were applied using different boundary packages available in Visual MODFLOW, Pro 4.1. The river-aquifer interaction was simulated using the river boundary package. Hydraulic conductivity values were applied to specific zones and these ranged from 9.8 to $26.6 \mathrm{~m} /$ day. Recharge due to rainfall and irrigation returns were assigned to respective zones. Pumping rates of $500 \mathrm{~m}^{3} /$ day, $1000 \mathrm{~m}^{3} /$ day, $1500 \mathrm{~m}^{3} /$ day, $2000 \mathrm{~m}^{3} /$ day and $2500 \mathrm{~m}^{3} /$ day were applied to appropriate areas of the model to simulate areas of stress. The zone budget shows a water balance deficit for the period

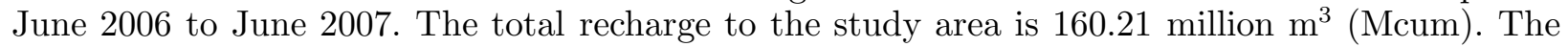
groundwater draft through pumping is of the order of $233.56 \mathrm{Mcum}$, thus leaving a deficit balance of $-73.35 \mathrm{Mcum}$. The sensitivity of the model to input parameters was tested by varying the parameters of interest over a range of values, monitoring the response of the model and determining the root mean square error of the simulated groundwater heads to the measured heads. These analyses showed that the model is most sensitive to hydraulic conductivity and recharge parameters. Three scenarios were considered to predict aquifer responses under varied conditions of groundwater bstraction.
\end{abstract}

\section{Introduction}

The alluvial areas of Uttar Pradesh have provided the most productive soils and aquifers in this district. The expansion of the irrigation network has brought about a spectacular increase in agriculture production in these areas over the last few decades. In the western part of Uttar Pradesh, and the study area, this has led to declining groundwater levels with detrimental impacts to groundwater resources and agricultural, domestic and industrial users. Long term groundwater level trends show an average decline of $0.88 \mathrm{~m} /$ year (Umar 2008). Groundwater serves as the main source of irrigation and is preferred over surface water irrigation for a number of reasons: groundwater is easily assessable and pumped due to shallow depth; pumping and operational costs are low; the Government

Keywords. Groundwater flow model; river-aquifer interaction; prediction scenario; Yamuna-Krishni; Muzaffarnagar. 
has provided sympathetic treatment to farmers in the form of free tubewell installations in early 60's and, later, a subsidized electricity policy. All these benefits have fuelled and stimulated groundwater irrigation.

Previous hydrogeological investigations in the area were mainly carried out by Central Ground Water Board (CGWB) and Groundwater Department of Uttar Pradesh (U.P.) government. Khan (1992) and Kumar (1994) carried out systematic hydrogeological investigations in Muzaffarnagar district and studied the first group of aquifer. They identified a number of blocks that were under- and over-exploited. A water balance study using water table fluctuation and tritium method was carried out in parts of Yamuna-Krishni interstream area by Ahmed and Umar (2008). The result of this water balance study showed a negative balance and place the area in an 'overexploited' category.

Aquifer modelling studies have been carried out in Krishni-Hindon interstream region (Gupta et al 1979) and Daha region (Gupta et al 1985). They have assessed the stream aquifer interaction as well as conjunctive use of surface water and groundwater in Daha region. Ala Eldin et al (2000) quantified the river-aquifer interaction in GangaMahaba sub-basin. The study also supported a new canal system to be introduced to check declining groundwater level. No modelling studies were carried out in the study area.

The purposes of the present work are to study the groundwater flow system in Yamuna-Krishni interstream region using steady and transient state numerical groundwater flow models and to investigate the effects of further groundwater development.

Anisotropic and heterogeneous three-dimensional flow of groundwater, assumed to have constant density, may be described by the partialdifferential equation.

$$
\begin{aligned}
& \frac{\mathrm{d}}{\mathrm{d} x}\left[K_{x x} \frac{\mathrm{d} h}{\mathrm{~d} x}\right] \frac{\mathrm{d}}{\mathrm{d} y}\left[K_{y y} \frac{\mathrm{d} h}{\mathrm{~d} y}\right] \\
& +\frac{\mathrm{d}}{\mathrm{d} z}\left[K_{z z} \frac{\mathrm{d} h}{\mathrm{~d} z}\right]-W=S_{s} \frac{\mathrm{d} h}{\mathrm{~d} t}
\end{aligned}
$$

where $K_{x x}, K_{y y}, K_{z z}$ are components of the hydraulic conductivity tensor, $h$ is potentiometric head, $W$ is source or sink term, $S_{s}$ is specific storage, and $t$ is time.

The finite-difference computer code Visual MODFLOW (McDonald and Harbaugh 1998) numerically approximates this equation, and were used to simulate the groundwater flow in the study area.

\section{The study area}

The study area, falling in Muzaffarnagar district of Uttar Pradesh in India, lies between latitudes $29^{\circ} 15^{\prime}$ and $29^{\circ} 41^{\prime} 45^{\prime \prime} \mathrm{N}$ and longitudes $77^{\circ} 05^{\prime}$ and $77^{\circ} 27^{\prime} \mathrm{E}$ and covers an area of about $1060 \mathrm{~km}^{2}$ (figure 1). The rivers, Yamuna and Krishni form the western and eastern boundaries of the study area. The river Yamuna flows in an irregular course from north to south with uncertain and ill-defined channels.

The topography of the sub-basin was based on a Digital Elevation Model obtained with the help of SRTM data. The altitude varies from 262 to 224 metres above mean sea level ( $\mathrm{m}$ amsl). The extreme north east part of the area has maximum elevations ranging from 262 to $254 \mathrm{~m}$ amsl. In general, the central track has got higher elevations which gently slope towards the rivers courses due west and east, i.e., towards the rivers Yamuna and Krishni, respectively.

On average, the study area receives $727 \mathrm{~mm}$ of annual rainfall but this can vary considerably. For instance, in the years 2005 and 2006, the annual rainfall was $606 \mathrm{~mm}$ and $435 \mathrm{~mm}$, respectively. Statistical results of historical rainfall data show that the rainfall is scanty and erratic in nature and mainly confined to 25-30 days a year.

\section{Model conceptualization and development}

The purpose of building a conceptual model is to simplify the field problem and organize the associated field data so that the system can be analyzed more readily (Anderson and Woessner 2002). The conceptualization include synthesis and framing up of data pertaining to geology, hydrogeology, hydrology, and meteorology.

\subsection{Groundwater level data}

A network of 60 existing observation wells were selected for water level monitoring. The water level monitoring programme was initiated in November 2005. The monitoring was carried out twice a year under a Ministry of Water Resources project. The depth of monitoring wells ranged between 10 and $30 \mathrm{~m}$ and these tap the first layer of the aquifer. Water levels were recorded from November 2005 to November 2007 at all observation points. Care was taken to try and obtain static groundwater levels, however, errors may have 


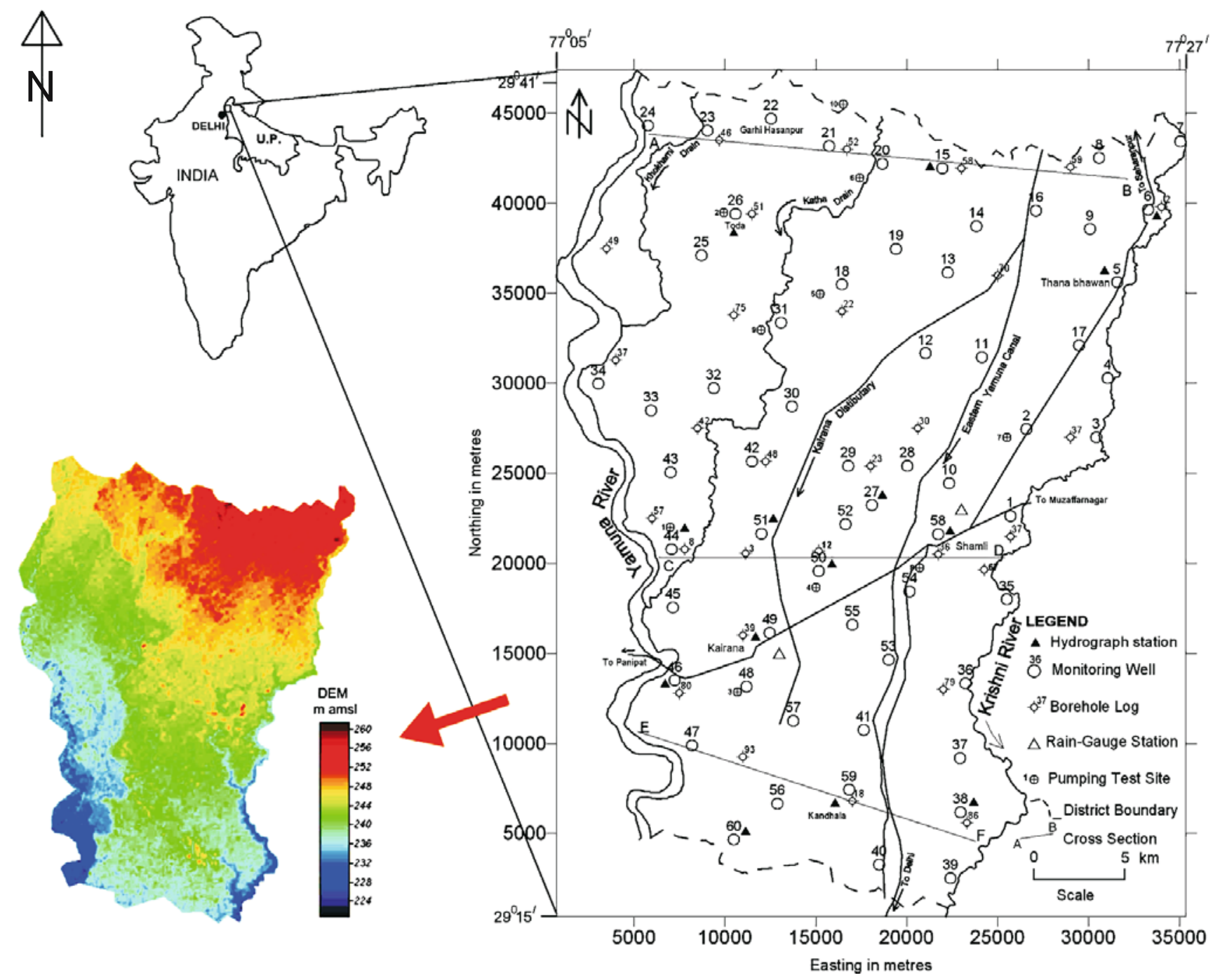

Figure 1. Location map of the study area.

been introduced because practically it was impossible to stop all pumping in an extensively cultivated area where concentration of groundwater abstraction structures are so high.

A perusal of a water table contour map (November 2006) shows that the general groundwater movement is from NNE to SSW (figure 2). However, local groundwater flows are also common which are very conspicuous and scattered away from the right bank of Eastern Yamuna Canal (EYC). These distorted patterns of flow direction in all likelihood are the outcome of over-drafting in these areas. The elevation of the water table ranges from $246 \mathrm{~m}$ amsl at extreme NE boundary of the district to $219 \mathrm{~m}$ amsl at the southern part of the study area. The EYC is recharging the aquifers in its vicinity. The contour patterns also show that the rivers Yamuna and Krishni are contributing to the aquifer system and hence are influent through most part of their tracks within the study area but in places both the rivers are receiving groundwater as well, which is indicated in the river-aquifer interaction section (table 1).

\subsection{Aquifer geometry}

Geologic information including geologic maps, cross sections and well logs were combined with information on hydrogeologic properties to define hydrostratigraphic units for the conceptual model (Anderson and Woessner 2002). On the basis of electrical and lithological logs four distinct aquifer groups were reported in the area. These groups lie at depth of 1-185, 115-235, 235-329 and 355-488 metres below ground level ( $\mathrm{m} \mathrm{bgl}$ ) (Bhatnagar et al 1982).

The present study was confined to the first group of aquifers. Lithological data of 27 boreholes were utilized for sketching horizontal and vertical disposition of aquifers and aquitards in the study area to a depth of $122 \mathrm{~m} \mathrm{bgl}$. The nature of the alluvial sediments is generally complex and is composed 


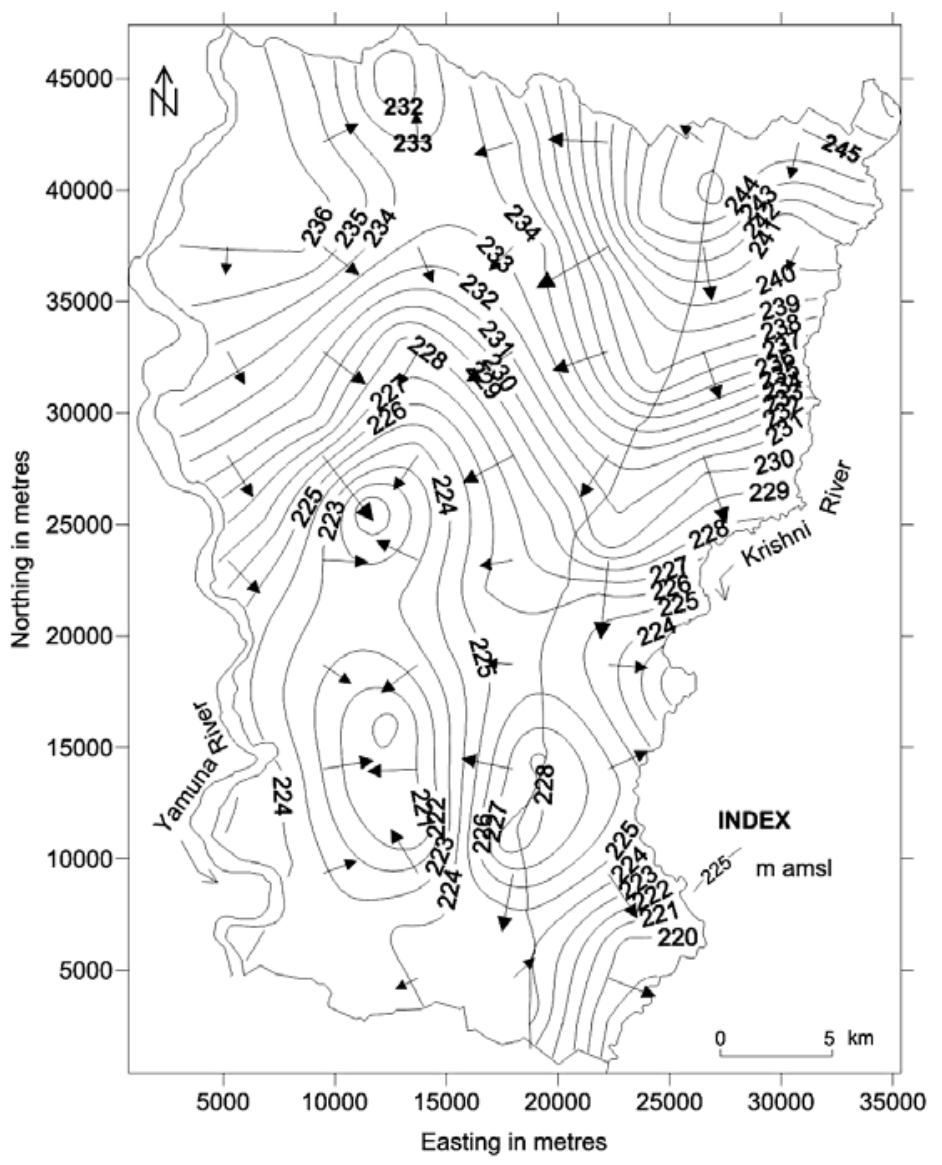

Figure 2. Water table contour map (November 2006).

Table 1. River-aquifer interaction.

\begin{tabular}{lcc}
\hline River & $\begin{array}{c}\text { Inflow* } \\
\text { (Mcum) }\end{array}$ & $\begin{array}{c}\text { Baseflow** } \\
\text { (Mcum) }\end{array}$ \\
\hline Yamuna & 6.39 & 0.52 \\
Krishni & 5.12 & 0.68 \\
\hline
\end{tabular}

${ }^{*}$ Inflow to study area, ${ }^{* *}$ Baseflow to river.

of a rapid alternation of sand and clay layers. The top clay bed is underlain by a granular zone, which extends downward to different depths varying up to a maximum of $122 \mathrm{~m} \mathrm{bgl}$. The granular zone is subdivided in places into two to three subgroups by the occurrence of sub-regional clay beds. Local clay lenses are also common throughout the area. By and large the aquifers down to a depth $122 \mathrm{~m}$ appear to merge with each other as the clay layers do not extend laterally to the entire area (figure 3).

A three-layer model was chosen over a single layer model to account for the presence of clay lenses and the inability of the software to recognize lenses. The top sandy layer contains the water table and is of variable thickness ranging from 15$84 \mathrm{~m}$ bgl. The simulation of aquifer geometry was done accordingly and clay lenses are presented as semi-permeable layers. The absence of clay horizon in a particular area was achieved by assigning a value of hydraulic conductivity equivalent to overlying and underlying aquifers (figure 4). The second layer, i.e., clay layer was assigned hydraulic conductivity values similar to the overlying and underlying layers at places where the clay layer was discontinuous as revealed by hydrogeological crosssections and fence diagram.

\subsection{Aquifer parameters}

The various aquifer parameters, such as hydraulic conductivity and specific yield/specific storage, were estimated and assigned to different layers, using data derived from previous studies (e.g., Bhatnagar et al 1982). The hydraulic conductivity values assigned to the model ranged between 9.8 and $26.6 \mathrm{~m} /$ day. A specific yield of 0.16 was applied uniformly to the entire area. Hydraulic conductivity values were obtained from seven pump tests (figure 1) and were assigned to seven distinct zones using the Thiessen Polygon method (figure 5), which involves the construction of polygon around the stations. This method is preferred 


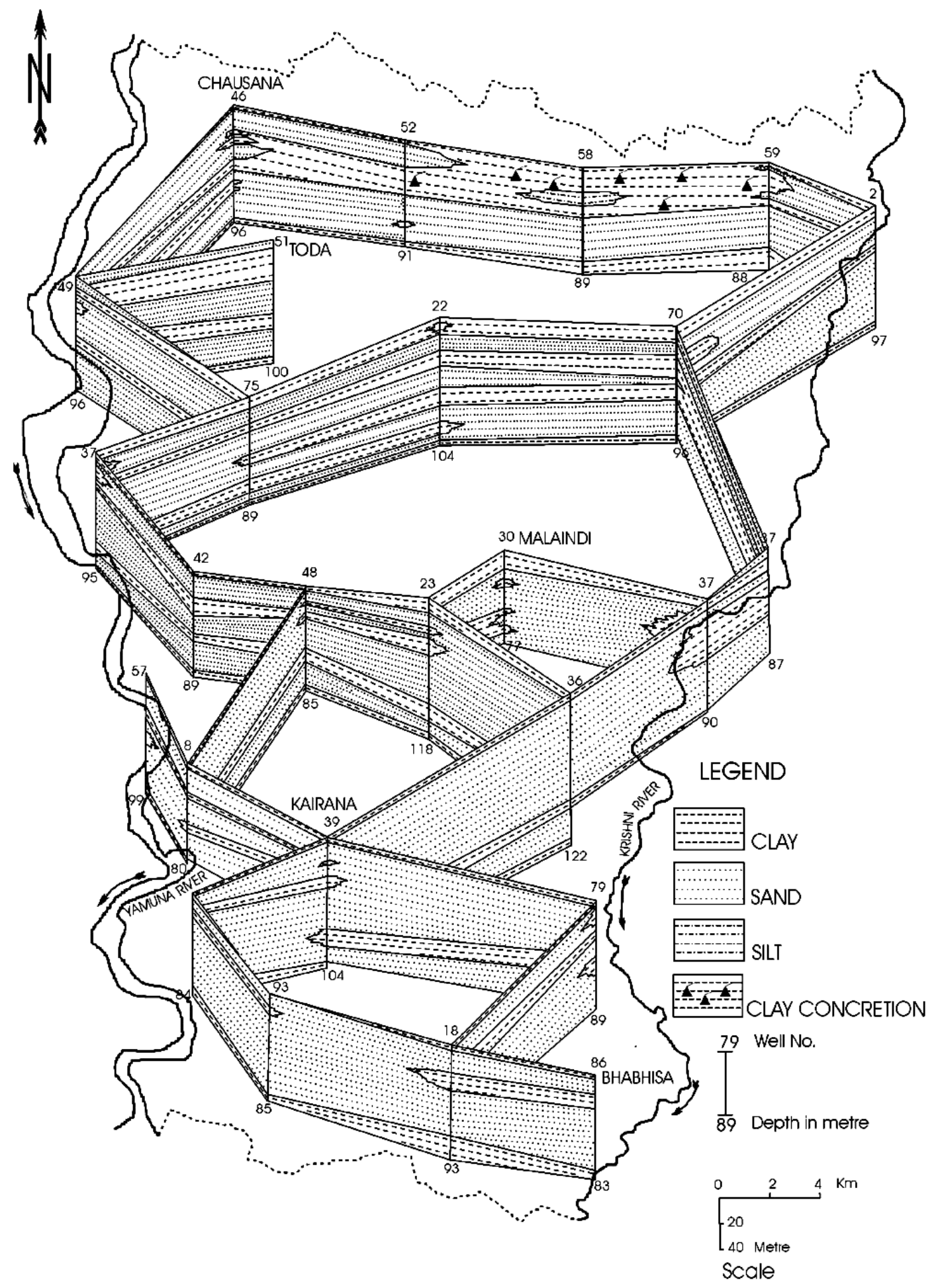

Figure 3. Fence diagram showing lateral and vertical aquifer disposition.

over contouring where data points are sparse. The conductivity values for the first and third layers remained the same as the both the layers are essentially similar. The second layer, being an aquitard, was given a conductivity value of $5 \mathrm{~m} /$ day. The second layer was also given similar conductivity values at places where clay layer was discontinuous (figure 4). The higher conductivity zones in the second layer were used to maintain the interconnectivity between the first and third layers. This assumption is based on the fact that clay layer is not a continuous layer and laterally pinched out and at places the first and third layers merge with each other to present a single bodied aquifer. 


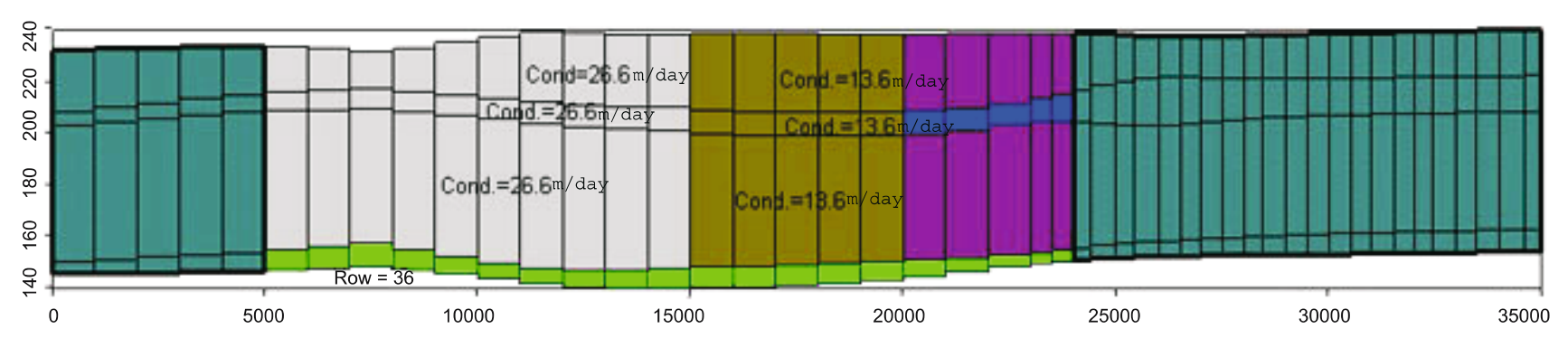

Figure 4. Simulated 3-layer model showing interconnectivity between overlying and underlying layers.

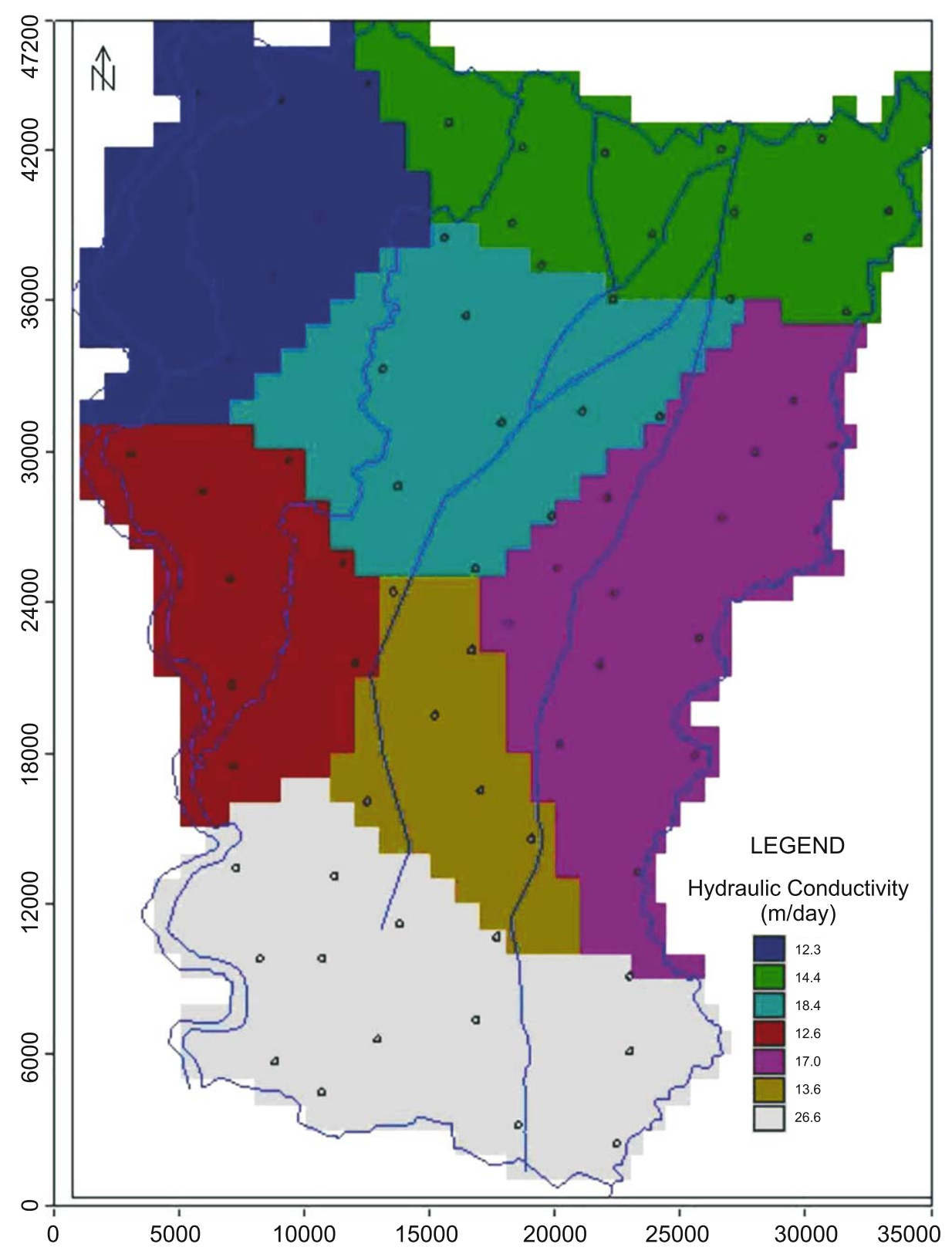

Figure 5. Hydraulic conductivity zones in the study area.

\subsection{Recharge}

Recharge from rainfall, irrigation return water and canal seepage was estimated using methodology given by the Groundwater Estimation Committee (1997). The GEC'97 recommendations incorporated a number of changes from its previous methodology bringing more clarity and realism 
in their application. Norms for return flow from groundwater and surface water irrigation are revised taking in to account the source of water, type of crop (paddy or non-paddy) and depth of groundwater level. Similarly norms are also provided to calculate recharge due to the seepage from unlined canals flowing through soil with some clay content and sand, and unlined canal in sandy soil with some silt content.

Initially, the estimated recharge values were calculated separately and applied to their respective grids. The rainfall recharge was calculated using the formula

$$
\begin{aligned}
R_{r f}= & h \times S_{y} \times A+D_{G}-R_{C} \\
& -R_{S W}-R_{g w}-R_{w c},
\end{aligned}
$$

where, $R_{r f}$ is the gross recharge due to rainfall and other sources including recycled water, $h$ is the rise in groundwater level, $A$ is the area of recharge assessment, $S_{y}$ is specific yield, $D_{G}$ is gross groundwater draft, $R_{C}$ is recharge due to seepage from canal, $R_{S W}$ is recharge from surface water irrigation, $R_{g w}$ is recharge from groundwater irrigation, and $R_{w c}$ is recharge from water conservation structure.

Recharge through groundwater irrigation and surface water irrigation was calculated separately. This was obtained as $R_{F}=R_{C} \times Q$. The seepage factor or return coefficient that was used was $0.15<R_{c}<0.45$ (GEC 1997). The infiltration factor is dependent upon several factors including soil type and texture, depth to water table, types of crop and method of application of water. It varies widely $(0.15-0.45)$ for the prevailing three major cropping patterns in the study area, i.e., Rabi, Kharif and Zaid (GEC 1997).

The EYC is the main canal traversed from north to south in the study area. It flows for about 300 days in a year. Kairana is its distributary which flows for about 100 days in a year (figure 1). Recharge through percolation from canals depends on the infiltration capacity of the canal sub-surface lithology, extent of wetted perimeter and length of canal.

$$
\begin{aligned}
\text { Canal seepage }= & \text { length } \times \text { wetted perimeter } \\
& \times \text { total running days } \\
& \times \text { specific loss }
\end{aligned}
$$

The estimation of recharge and discharge parameters were done for monsoon and non-monsoon periods. The estimated values were then applied to the respective grids in the model using recharge boundaries (figure 6). The total recharge estimated was in accordance with water table fluctuation method (Healy and Cook 2002) and Groundwater Estimation Committee (GEC 1997) methodology for groundwater resource estimation. Recharge through irrigation returns and seepage through unlined canals was estimated using standard norms recommended by GEC-97. Site specific recharge data are often used purely as fitting parameters during model calibration (Varni and Usunoff 1999) where site specific information is available, and an assumed fraction of this is commonly assigned as the recharge boundary condition (Kennett-Smith et al 1996; Hsu et al 2007). Such assumptions are adequate for the long term simulation of regional groundwater flow system (Jyrkama et al 2002) and was used during the present study.

\subsection{Groundwater draft through pumping}

A database of existing borewells in the study area was created from several field visits over the period November 2005 to November 2007. A borewell census from the Statistical Department was also used for the same purpose. Three types of wells were categorized on the basis of their yield. The state tubewells, governed by State Tubewell Department, have a discharge rate of $1500 \mathrm{~L} / \mathrm{min}$. Private electric motor and private diesel engine borewells have discharge rates in the order of $250 \mathrm{~L} / \mathrm{min}$ and $60 \mathrm{~L} / \mathrm{min}$, respectively. The duration of pumping mainly depends on electric power supply, tubewell maintenance and season of the year. Simulated pumping rates of $500 \mathrm{~m}^{3} /$ day, $1000 \mathrm{~m}^{3} /$ day, $1500 \mathrm{~m}^{3} /$ day, $2000 \mathrm{~m}^{3} /$ day and $2500 \mathrm{~m}^{3}$ /day were used in the pumping well package.

\subsection{Boundary conditions}

Every model requires an appropriate set of boundary conditions to represent the system's relationship with the surrounding area. The western and eastern boundaries representing the Yamuna and Krishni rivers, respectively, were assigned as river boundaries (figure 6). For these boundaries, river head and river bed bottom elevations were assigned to appropriate grids after carrying out several field visits. The river head and bed bottom elevations at the initial and final point of river Yamuna are 235 and $234 \mathrm{~m}$ amsl and 224 and $223.5 \mathrm{~m}$ amsl, respectively. For river Krishni, the river head and bed bottom elevations at the initial and end points are 240 and $239 \mathrm{~m}$ amsl and 220.8 and $220.6 \mathrm{~m}$ amsl, respectively. River bed conductance varies between 150 to 100 and 50 to $30 \mathrm{~m}^{2} /$ day for the Yamuna and Krishni rivers, respectively.

General head boundaries (GHB) were assigned at the northern and southern edges of the model. 


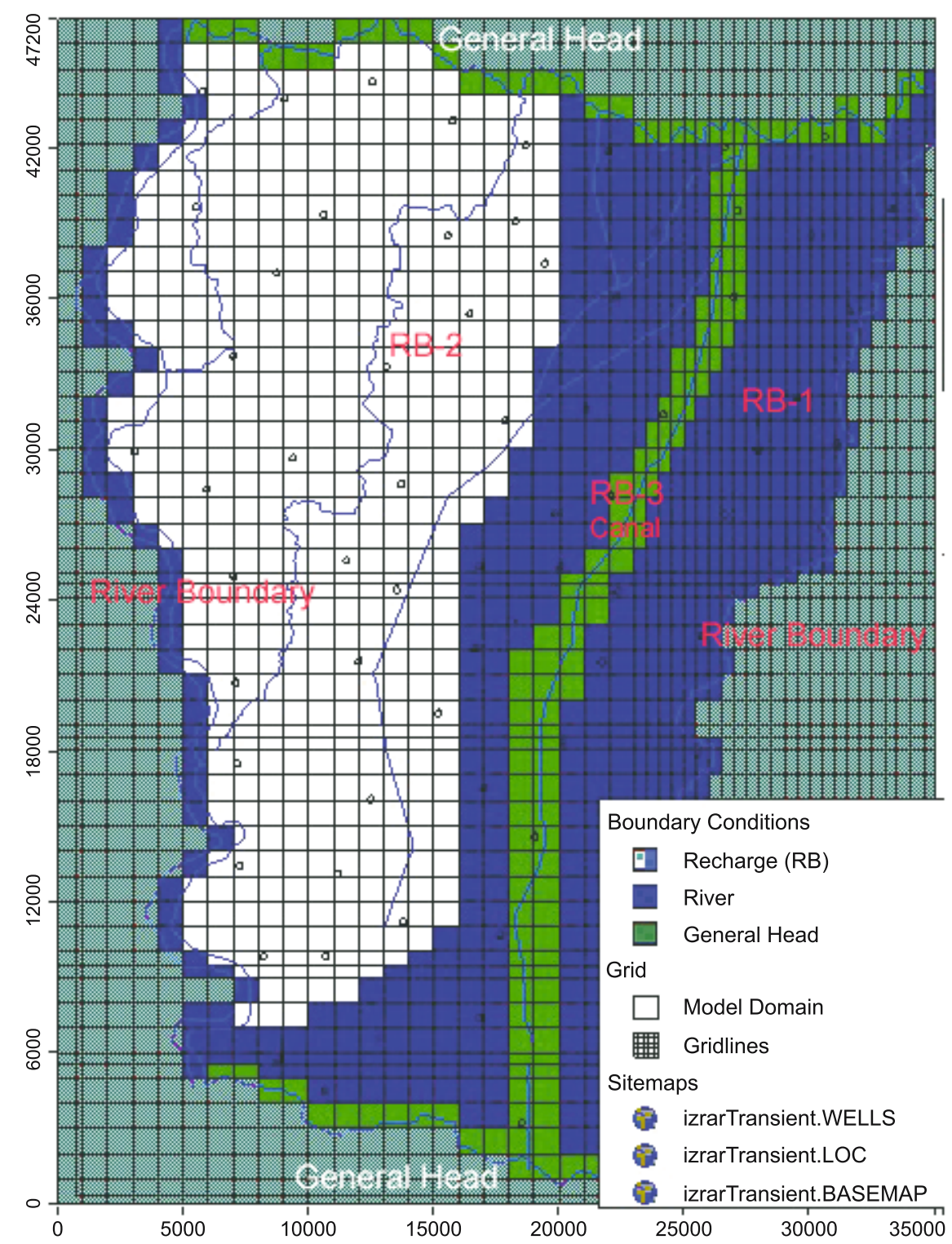

Figure 6. Map showing grid pattern, recharge zone and boundary conditions.

Heads were assigned to the GHB with the help of historical water level data.

\section{Model design and software}

The Yamuna-Krishni Model was assigned a uniform grid pattern of $1000 \times 1000 \mathrm{~m}$ (figure 6 ). The choice between analytical and numerical models is somewhat crucial and depends on the complexity of hydrogeologic conditions and the availability of field data. In many situations, with relatively scarce field data and simple site geometry, analytical models may be appropriate and vice-versa. Keeping this in view, the present study was subjected to a numerical solution of groundwater flows. The groundwater flow modelling included the development of a mathematical model to simulate hydrogeological conditions of ground water flow systems in the area.

The finite-difference groundwater model Visual MODFLOW 4.1 Pro was used in the present study. MODFLOW is a computer program that numerically solves the three-dimensional ground-water flow equation for a porous medium by using a finite-difference method (Waterloo Hydrogeologic Inc. 2005). In the finite difference method (FDM), a continuous medium is replaced by a discrete set of points called nodes and various hydrogeological parameters are assigned to each of these nodes.

\section{Model calibration}

The purpose of model calibration is to establish that the model can reproduce field measured heads 

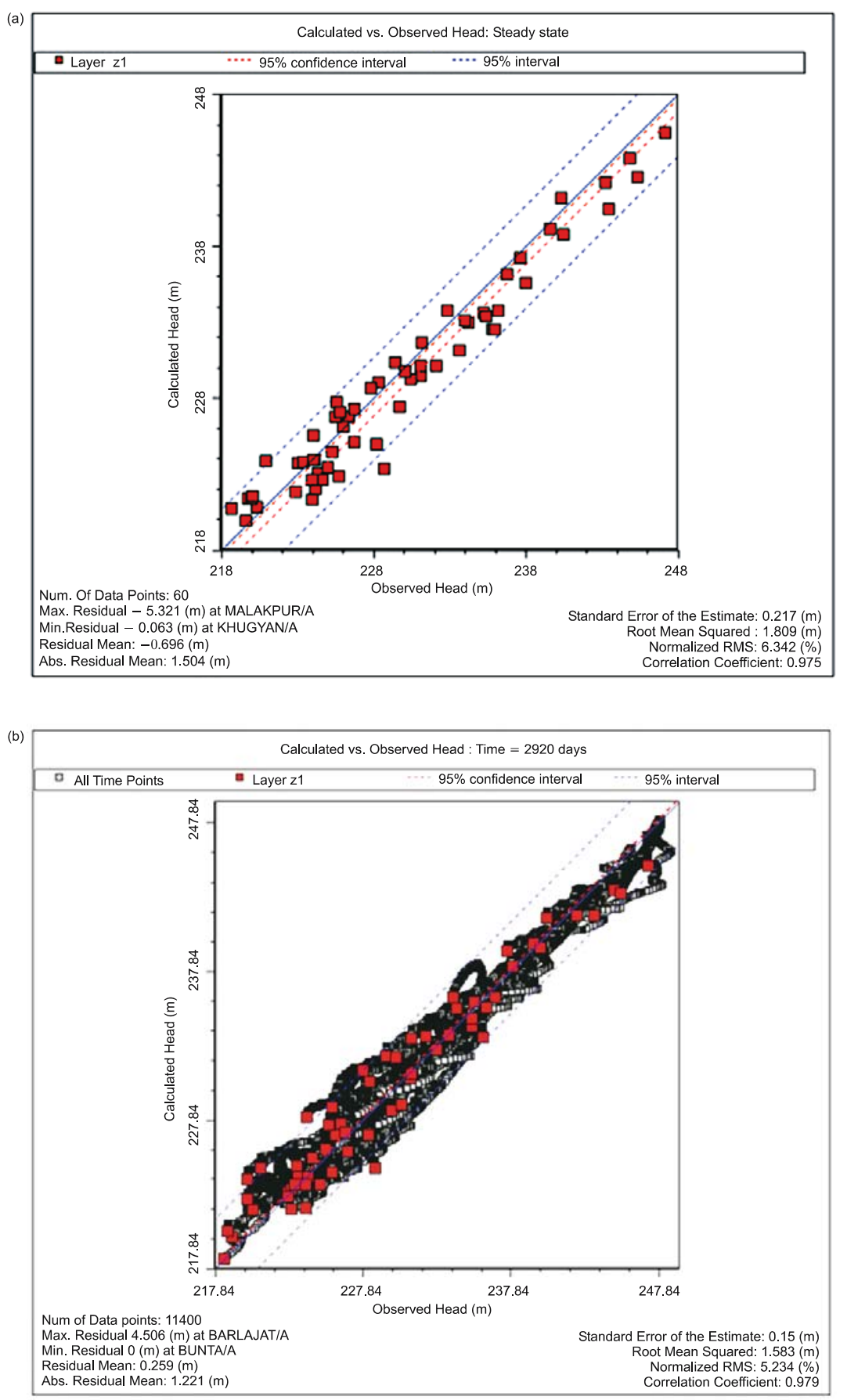

Figure 7. (a) Computed vs. observed head for steady state (November 2006). (b) Computed vs. observed head for transient state (June 2007-June 1999).

and flows. Calibration is carried out by trial and error adjustment of parameters or by using an automated parameter estimation code.

\subsection{Steady state calibration}

Steady state conditions are usually taken to be historic conditions that existed in the aquifer before significant development has occurred (i.e., inflows are equal to outflows and there is no change in aquifer storage). In this model, quasisteady state calibration comprised the matching of observed heads in the aquifer with hydraulic heads simulated by MODFLOW during a period of unusually high recharge. The calibration was made using 60 observation wells monitored during November 2006. Hydraulic conductivities estimated from pumping tests were used as initial values for the steady state simulation. By trial and error calibration, the conductivity values were 
increased during many sequential runs until the match between the observed and simulated water level contours were obtained.

The computed water level accuracy was judged by comparing the mean error, mean absolute and root mean square error calculated (Anderson and Woessner 1992). Mean error is $-0.066 \mathrm{~m}$. Root mean square (RMS) error is the square root of the sum of the square of the differences between calculated and observed heads, divided by the number of observation wells, which in the present simulation is $1.8 \mathrm{~m}$ (figure 7a). The absolute residual mean is $1.5 \mathrm{~m}$. The absolute residual mean $|\bar{R}|$ is similar to the residual mean except that it is a measure of the average absolute residual value defined by the equation:

$$
|\bar{R}|=\frac{1}{n} \sum_{i=1}^{n}\left|R_{i}\right| .
$$

The absolute residual mean measures the average magnitude of the residuals, and therefore provides a better indication of calibration than the residual mean (Waterloo Hydrogeologic Inc. 2005).

\subsection{Transient state model}

It is quite possible that the aquifer system may attain steady state conditions at more than one time period as at any time period if the flows get balanced and the water levels do not change over that period, the system remains in the steady state condition. However, in practice and moreover in India where in most cases, over-exploitations are common, it is very difficult to get the aquifer in the steady state condition unless we go much beyond in time in the past which limits the data availability. Thus in this case, the aquifer system was found to be in near steady state during November 2006, it was chosen to run and calibrate the model under steady state for this period and the calibrated transmissivity distribution was obtained. Subsequently, the model was calibrated to transient state from June 1999 to June 2007. MODFLOW-2000 allows individual stress periods in a single simulation to be either transient or steady state or entire simulation to be either steady state or transient. Steady state and transient stress periods can occur in any order (Waterloo Hydrogeologic Inc. 2005). Since data on various flows in transient state were available for a period of 1999 to 2007, simulation was performed for that period taking the 1999 water levels as initial condition and then the simulation was carried out under transient conditions 1999 onward to 2006. The time steps in transient simulations run from November 1999 to
June 2007 were divided in to 18 time steps. Each year was also divided in to two stress periods of 152 days (monsoon period) and 213 days (nonmonsoon period), respectively. Recharge boundaries were initially set using a 30-day stress period, which was gradually increased to 152 and 213 days. The actual amount of recharge was calculated for each year using GEC'97 methodology. Recharge through irrigation return flows and canal seepage was calculated using specific norms. Visual MODFLOW uses boundary conditions imposed by the user to determine the length of each stress period. The initial hydraulic conductivity values of the steady state model were used as the values for the transient state model. After a number of trial runs, where the input/output stress were varied, computed water levels were matched fairly reasonably to observed values. The RMS for the transient model is $1.58 \mathrm{~m}$ (figure 7b). Also it was assured that the model water levels during November 2006 reasonably matched with the observed water levels during that period.

The computed water level of November 2006 indicates a prevailing trend of groundwater flow in the interstream region (figure 8). The observed preand post-monsoon water levels for selected observation wells for the period 1999-2007 were used for the transient state calibration. It should be noted that estimation of recharge, as a fraction of annual rainfall, was a first approximation: actual recharge depends upon total precipitation, its frequency and other inputs such as irrigation returns and canal seepage. A comparison of observed and computed heads at different observation wells is shown in figure 9 .

In the transient state model, for time step 19992005 only rainfall recharge was known. The impact of irrigation returns and canal seepage were estimated by trial and error, by matching observed and measured heads, to provide a value of total recharge. In this way, model fluxes were also calibrated.

\section{Results}

\subsection{River-aquifer interaction}

In an unconfined aquifer, river-aquifer interactions are sensitive and need to be handled with care. Interactions between an alluvial aquifer system and river are influenced by the spatial arrangement of hydrofacies at the interface between the river and the underlying aquifer (Woessner 2000). Modelling studies that include river-aquifer interactions need to be focused on the impacts of regional scale, water management and conjunctive use issues (Onta et al 1991; Reichard 1995; 

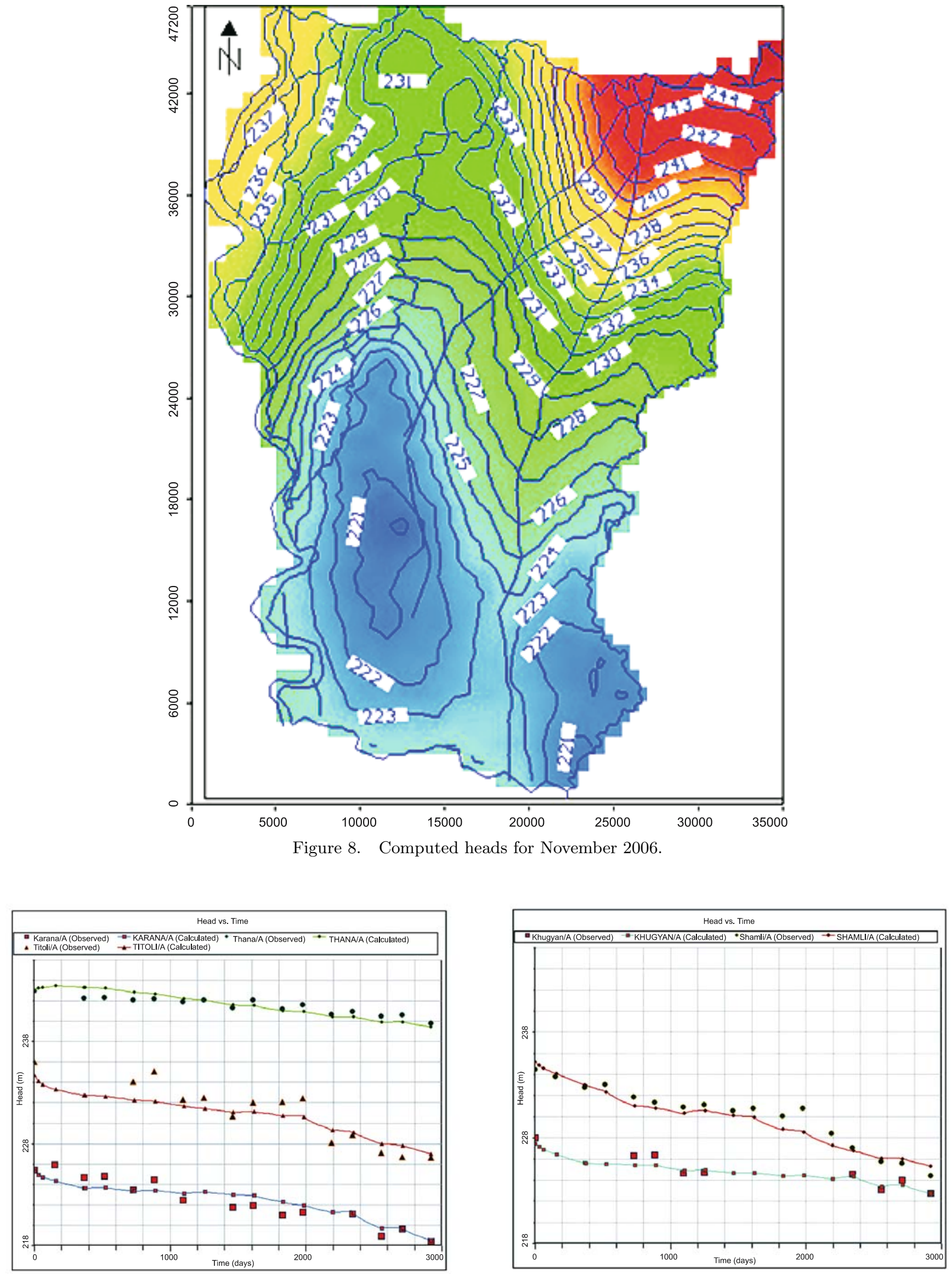

Figure 9. Comparison of observed and calculated heads at selected observation (June 1999-June 2007). 
Wang et al 1995). For instance, the accuracy of groundwater inflow or outflow estimates, made from the difference in river flows at the beginning and the end of a reach, is limited because flow differences are often small compared to the total river flow (Rushton 2006). Also, regional average streambed thickness and hydraulic conductivities used in large scale models affect stream-aquifer interactions (Anderson and Woessner 1992).

The Yamuna and Krishni rivers form western and eastern boundaries of the area and actively participate in groundwater dynamics. For modelling purposes, both rivers were divided in to five segments such that each segment had representively uniform river stage, bed bottom and conductance. The effect of groundwater extractions (pumping) in the flood plains of river Yamuna, which have a strong influence on the river's characteristics, also had to be considered. The rivers were assumed to be between 3 and $25 \mathrm{~m}$ wide with a depth of water between 0.4 and $1.0 \mathrm{~m}$. Twodimensional $x-z$ (profile) steady-state numerical model solutions were used to explore the interaction between the river and aquifer and a variety of boundary conditions were considered, including recharge to the water table. The altitudes of river stage and river bed bottom are measured accurately. The river boundary package was employed for both rivers. In the zone budget package, both the rivers were treated as individual zones and subsequently their flux was calculated by model itself. The quantitative river-aquifer interaction is reported in table 1.

\subsection{Zone budget}

The zone budget package calculates sub-regional water budgets using the results from the MODFLOW simulation. The estimated recharge values were initially used in the recharge boundaries to command, non-command and canal tracks. The heads were assigned to river stage by applying the river boundary package.

The water balance of the model for June 2006 to June 2007 is as follows: the total recharge to the Yamuna-Krishni sub-basin is 139.61 Mcum. The total annual draft through pumpage is 229.83 Mcum. The subsurface horizontal inflows and outflows are 9.09 and 2.53 Mcum, respectively. The result shows a deficit balance of 73.35 Mcum. The various components of groundwater balance are tabulated in table 2 .

\subsection{Model sensitivity}

The purpose of the model was to predict future situations and for that it was essential to establish that the model could simulate field-measured heads
Table 2. Components of groundwater balance using MODFLOW.

\begin{tabular}{lcc}
\hline $\begin{array}{l}\text { Components of } \\
\text { groundwater balance }\end{array}$ & $\begin{array}{c}\text { Monsoon } \\
\text { (Mcum) }\end{array}$ & $\begin{array}{c}\text { Non-monsoon } \\
\text { (Mcum) }\end{array}$ \\
\hline Direct recharge & 93.00 & 46.61 \\
Subsurface inflows & 3.05 & 6.04 \\
Draft through pumpage & 111.23 & 118.6 \\
Subsurface outflows & 1.39 & 1.14 \\
\hline
\end{tabular}

and flows. By trial and error adjustments, the conductivity values were increased during many sequential runs until a match between observed and simulated water level contours were obtained. Sensitivity analyses help in understanding the significance of each individual parameter during model simulations. The purpose of a sensitivity analysis is to quantify the uncertainty in a calibrated model caused by uncertainty in the estimates of aquifer parameters, stresses and boundary conditions (Senthil Kumar and Elango 2004). During the sensitivity analysis, calibrated values for the hydraulic conductivity, storage parameters, recharge and boundary condition are systematically changed within appropriate ranges, which are determined from the range of data values and professional experience. The magnitude of the change in heads in the calibrated solution is a measure of the sensitivity of the solution to that particular parameter. The computed head values should mimic observed head values at most of the well locations.

A sensitivity analysis may also test the effect of changes in particular values other than the head. In the present modelling exercise the sensitivity of hydraulic conductivity and recharge was examined. The conductivity varies from 9.8 to $26.6 \mathrm{~m}$ /day. Initially the permeability values were taken from the existing pump test and steady state water levels for November 2006. The comparison of computed heads and observed heads showed a mean error of $-0.49 \mathrm{~m}$, mean absolute error of $1.3 \mathrm{~m}$ and RMS error of $1.68 \mathrm{~m}$. During the first sensitivity analysis the conductivity values were increased by $10 \%$, which increased the RMS error to $1.703 \mathrm{~m}$. Second and third runs were made with $20 \%$ and $50 \%$ increases in the conductivity values, which again increased the RMS error. A fourth run was made such that the minimum values of conductivity (i.e., 9.8 and $10.1 \mathrm{~m} /$ day), encompassing an area close to river Yamuna, were raised by $25 \%$. The forth run provided a better match of observed and simulated heads with an RMS error of $1.58 \mathrm{~m}$. Thus the initial permeability of 9.8 and $10.1 \mathrm{~m} /$ day were increased to 12.25 and $12.6 \mathrm{~m} /$ day along the river Yamuna. The rest of the values represent actual conductivity values taken from the pumping tests. 


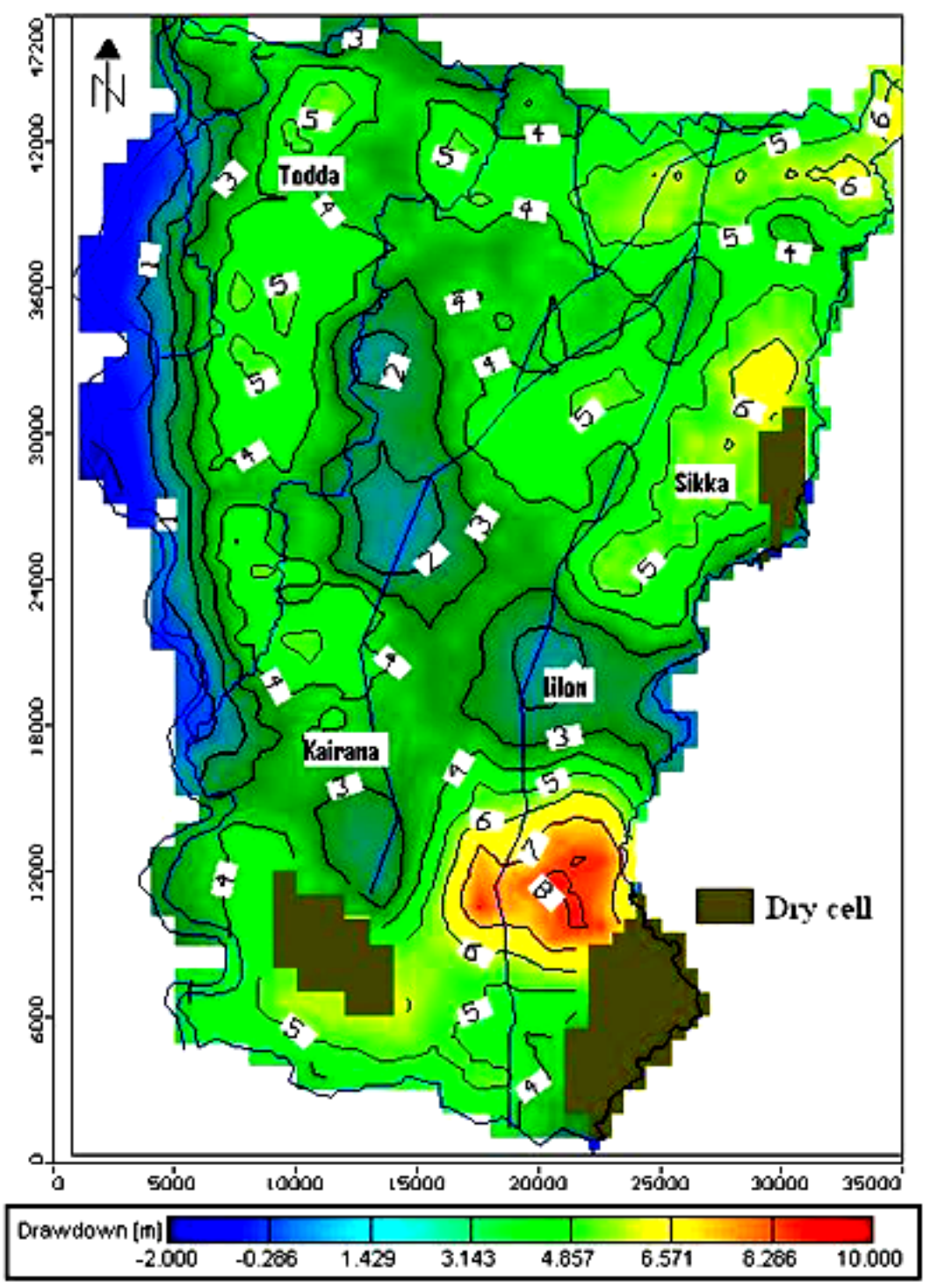

Figure 10(a). Drawdown and dry cell in scenario 1.

The recharge parameter was changed during the next sensitivity analysis run. It represents the recharge due to rainfall and irrigation return flows and canal seepages. Initially, the estimated recharge values were calculated separately for command, non-command and canal tracks and applied to their respective grids. The recharge sensitivity of the model was tested for a $1 \%$ increase and decrease in this parameter and these showed RMS errors of 1.64 and $2.03 \mathrm{~m}$, respectively. Thus, the model was more sensitive to recharge than conductivity.

\subsection{Predictions and assessment (2007-2014)}

Three different scenarios were considered to predict the behaviour of the groundwater regime in the Yamuna-Krishni sub-basin during the period 2007-2014. These scenarios are explained below.

\subsubsection{Scenario 1: Increase in current withdrawal rate}

During this prediction scenario, the ongoing abstraction rate was increased by $20 \%$ from 2007 to 2014 , over a period of 8 years. This increase is in line with present rate of consumption. The initial recharge of November 2006 was kept constant throughout the prediction period. It was observed during this prediction run that the area in the vicinity of river Krishni was drastically affected and four observation wells, i.e., Bhabhisa, Bhanera, Kaidi and Sonta went dry in the 2014 time period. A maximum drawdown of $10 \mathrm{~m}$ was observed around Makhmulpur village. The minimum drawdowns were observed at locations close to the river Yamuna, e.g., Khurgyan, Chontra and Bhari observation wells where the drawdown was $<2$ m (figure 10a). 


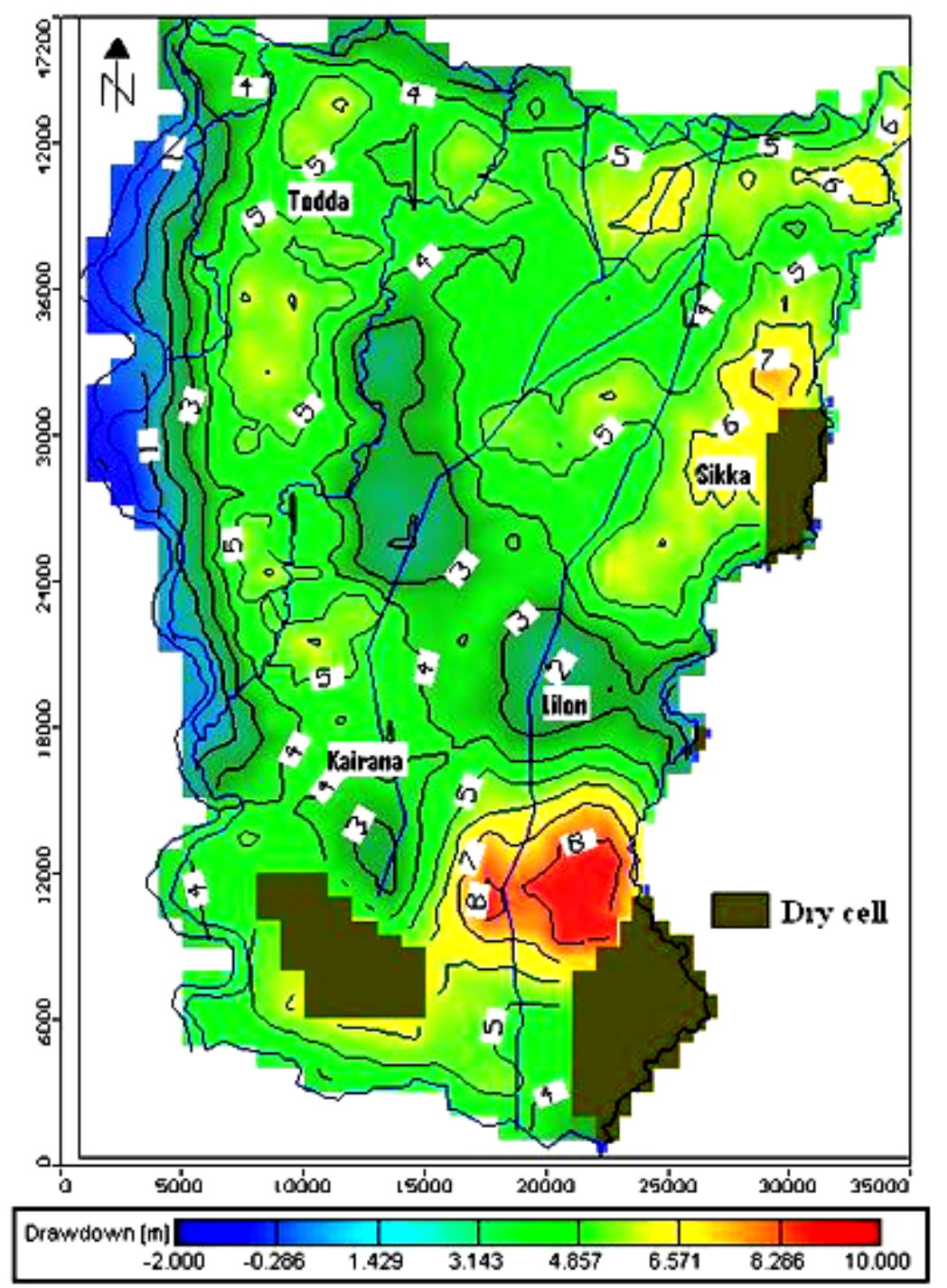

Figure 10(b). Drawdown and dry cell in scenario 2.

\subsubsection{Scenario 2: Decrease in recharge}

In this prediction scenario the combined effect of increasing abstraction rates by $20 \%$ and reducing rainfall by $20 \%$ was examined. The combined impact of both these factors showed a maximum drawdown of $10 \mathrm{~m}$ occurring in wells locationed at Makhmulpur, Malakpur and Salpa, close to river Krishni. The minimum drawdown of $<2 \mathrm{~m}$ was observed at Chontra and Bhari observation wells. In this scenario five observation wells (i.e., Gangeru, Bhabhisa, Bhanera, Kaidi and Sonta) went dry by 2014. The extent of dry cells is large in comparison to scenario 1 (figure 10b).

\subsubsection{Scenario 3: Introducing recharge through canals in non-command area}

In order to mitigate the groundwater depletion and drying up of wells at some location in the study area, additional recharge of $300 \mathrm{~mm} /$ year was applied to the dry Kairana distributary and to its irrigation channels. This is again a practically possible scenario. The extent of dry cells was reduced after introducing this additional recharge (figure 10c). Thus recharge through surface water structures and through water harvesting can positively help affected areas.

\section{Discussion and conclusion}

Groundwater overexploitation from shallow aquifers, which results in a negative or deficit groundwater budget, has posed a threat to the sustainability of shallow aquifers in parts of the Central Ganga Plain. Groundwater flow modelling studies were carried out to provide insight into this. This approach simulates groundwater flow for steady and transient conditions, provides 


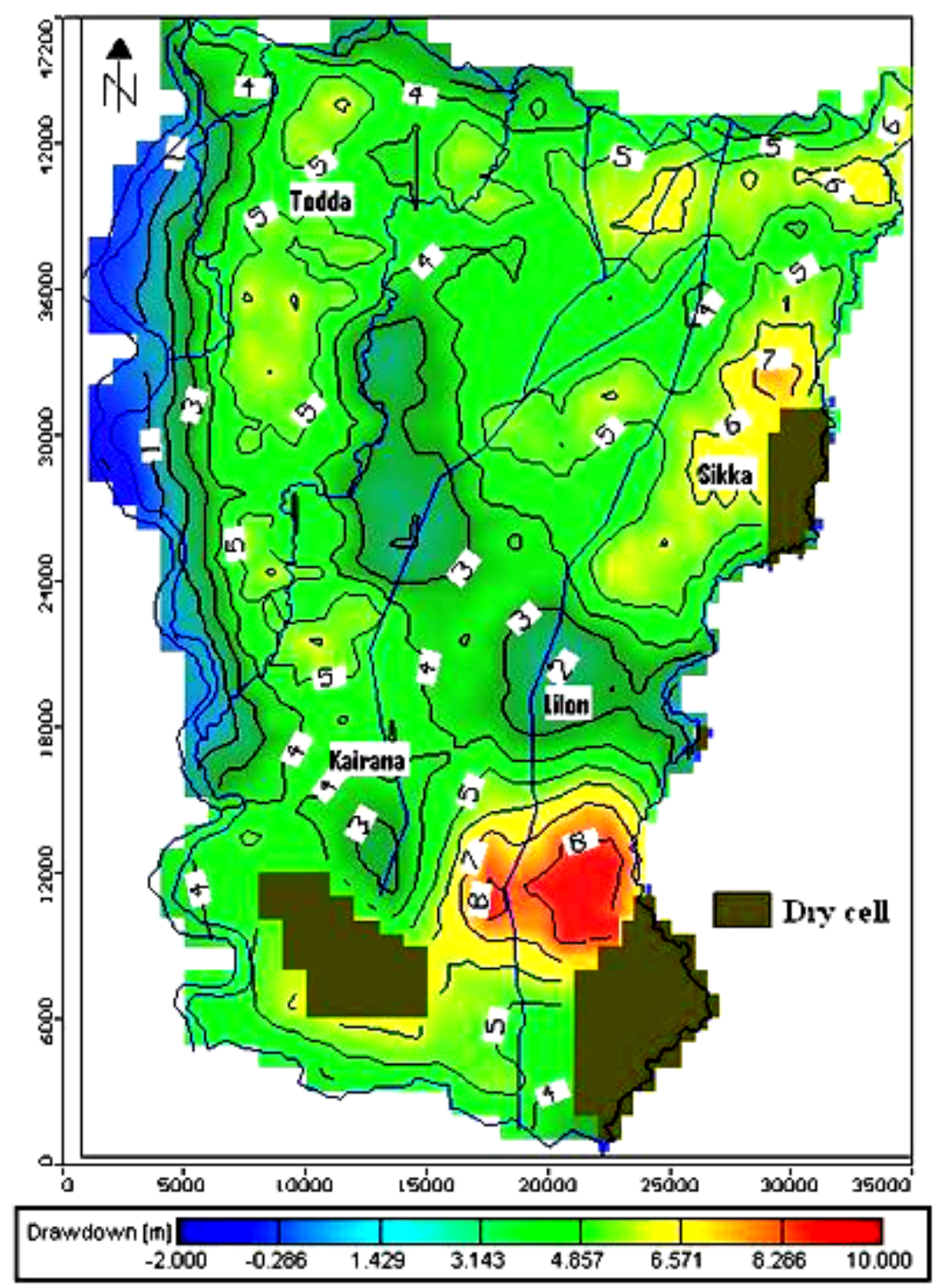

Figure 10(c). Drawdown and dry cell in scenario 3.

quantitative estimates of river-aquifer interactions and enables forecasts of changes to the water table to be evaluated under different stresses and recharge conditions.

The time period of November 2006 was taken as the initial condition for steady-state model calibration. Model calibration for steady state conditions shows good agreement between observed and simulated water level contours. The water balance of the model for June 2006 to June 2007 was as follows: the total recharge to the Yamuna-Krishni sub-basin was 139.61 Mcum. The total annual draft through pumpage was 229.83 Mcum. The subsurface horizontal inflows and outflows were 9.09 and 2.53 Mcum, respectively. The result shows a deficit balance of 73.35 Mcum.

Three scenarios were considered to predict aquifer responses under different conditions of groundwater abstraction and additional recharge through distributary and drains in deficit areas.

According to prediction scenario 1, with a $20 \%$ increased groundwater abstraction rate, the maximum drawdown will reach $10 \mathrm{~m}$ in the year 2014 . The area in close vicinity to river Krishni shows high rate of decline at four observation wells, which went dry in this scenario. The minimum drawdown was observed in the area close to river Yamuna. In the second scenario, the rainfall was reduced by $20 \%$ and groundwater abstraction was kept the same as scenario 1 . This shows that the maximum drawdown was very high $(10 \mathrm{~m})$. In this scenario, the area close to Krishni and the southern part of the study area showed declines in water levels and a dewatering of shallow aquifers at five locations. In the third prediction scenario, additional recharge was given to the Kairana distributary 
and its irrigation channels, which had the effect of reducing the extent of dry cells. Thus, to mitigate water table declines artificial recharge and conjunctive use of water is suggested, or there has to be a reduction in groundwater abstractions.

In order to safeguard and sustain the groundwater aquifers, the following recommendations are proposed:

- Groundwater abstractions should be focused on deeper aquifers. The study carried out by CGWB in alluvial parts of central Ganga Plain revealed the existence of a huge reserve of groundwater in the deeper aquifers, which have not been fully utilized. The thickness of the alluvium in the area exceeds to $1000 \mathrm{~m}$ below ground level and only a small fraction of this is under active circulation due to prevailing shallow groundwater developments. Therefore, it is suggested that the second and third aquifers should be tapped.

- In the past, every village in western Uttar Pradesh boasted of having ponds that were a very good source of groundwater recharge, at least locally. During the field surveys it was observed that these ponds have disappeared due to encroachment by local people. This has retarded the groundwater recharge of shallow aquifer. Thus a revival of such structures is recommended.

- Conjunctive use of surface water and groundwater resources is the optimal method of obtaining maximum possible water development.

- There is an urgent need to enforce some regulation on groundwater pumpage to avoid misuse of groundwater resource.

\section{Acknowledgements}

The financial assistance received from INCOH, Project No. 23/36/2004-R\&D, Ministry of Water Resources, Government of India is gratefully acknowledged. The suggestions received on this manuscript from Prof. M Razack, Department of Hydrogeology, University of Poitiers, France and two reviewers are gratefully acknowledged. We are also thankful to Mr J M Ashworth, a very senior hydrogeologist for editing the manuscript. The authors are also thankful to the Chairman, Department of Geology, Aligarh Muslim University, Aligarh for providing the basic facilities that made this study possible.

\section{References}

Ahmed I and Umar R 2008 Hydrogeological framework and water balance studies in parts of Krishni-Yamuna interstream area, western Uttar Pradesh, India. J. Environ. Geol. 53(8) 1723-1730.

Ala Eldin M E H, Ahmed M S, Gurunadha Rao V V S and Dhar R L 2000 Aquifer modeling of the GangaMahawa sub-basin, a part of the Central Ganga Plain, Uttar Pradesh; India. Hydrol. Process. 14 297-315.

Anderson M P and Woessner W W 1992 Applied groundwater modeling; Academic Press, San Diego.

Anderson M P and Woessner W W 2002 Applied groundwater modeling - Simulation of flow and advective transport.

Bhatnagar N C, Agashe R M and Mishra A K 1982 'Subsurface Mapping of Aquifer System' Water balance study of Upper Yamuna Basin, Section-Hydrogeology, Technical report No. 2, Upper Yamuna Project, CGWB, NW region, Chandigarh.

Gupta C P, Thangarajan M and Rao V V S G 1979 Electrical analog model study of aquifer in Krishni-Hindon interstream region, Uttar Pradesh, India; Groundwater 17(3) 284-292.

Gupta C P, Ahmad S and Rao V V S G 1985 Conjunctive utilization of surface water and groundwater to arrest the water level decline in an alluvial aquifer; J. Hydrol. 76(3/4) 351-361.

Healy R W and Cook P G 2002 Using groundwater levels to estimate recharge; J. Hydrogeol. 10(1) 91-109.

Hsu K C, Wang C H, Chen K C, Chen C T and Ma K W 2007 Climate-induced hydrological impacts on the groundwater system of the Pingtung Plain, Taiwan; J. Hydrogeol. 15(5) 903-913.

Jyrkama M I, Skyes J F and Normani S D 2002 Recharge estimation of transient groundwater modeling; Groundwater 40(6) 638-648.

Kennett-Smith A, Narayan K and Walker G 1996 Calibration of a groundwater model for the upper south east of South Australia. Div. report 96-2.CSIRO Division of Water Resources, Canberra, Australia.

Khan A M 1992 Report on systematic hydrogeological surveys in parts of Muzaffarnagar District, U.P., Central Groundwater Board, Northern Region, Lucknow, India.

Kumar S 1994 Report on Hydrogeological and Groundwater Resources Potential, Muzaffarnagar Districts, U.P. Central Ground Water Board, Northern Region, Lucknow.

McDonald M G and Harbaugh A W 1988 A modular three dimensional finite-difference groundwater flow model. USGS Open File Report 83-875. USGS, Washington, D.C.

Ministry of Water Resources 1997 Report of the groundwater resource estimation committee - Groundwater resource estimation methodology, Government of India, New Delhi.

Onta P R, Dasgupta A and Harbor R 1991 Multistep planning model for conjunctive use of surface-water and groundwater resources; J. Water Resources Planning and Management 117(6) 662-678.

Reichard E G 1995 Groundwater surface water management with stochastic surface water supplies - A simulation optimization approach; Water Resources Research 31(11) 2845-2865.

Rushton K 2006 Representation in regional models of saturated river-aquifer interaction for gaining losing rivers; J. Hydrol. 334 262-281.

Senthil Kumar M and Elango L 2004 Three dimensional mathematical model to simulate groundwater flow in the lower Palar River basin, southern India; J. Hydrogeol. 12(3) 197-208.

Umar R 2008 Groundwater Flow Modeling and Aquifer Vulnerability Assessment studies in Yamuna-Krishni sub-basin, Muzaffarnagar District, Ministry of Water 
Resources, Government of India (Unpublished progress report), 51p.

Varni M R and Usunoff E J 1999 Simulation of regional scale groundwater flow in the Azul River Basin, Buenos Aires province, Argentina; J. Hydrogeol. 7(2) 180-187.

Wang C C, Mortazavi B, Liang W K, Sun N Z and Yeh W W G 1995 Model development for conjunctive use study of the San Jacinto Basin, California; Water Res. Bull. 31(2) 227-241.

Waterloo Hydrogeologic Inc. 2005 Visual MODFLOW v.4.1, User's Manual, Waterloo, Ontario, Canada.

Woessner W W 2000 Stream and fluvial plain groundwater interactions: Rescaling hydrogeologic thought; Groundwater 38(3) 423-429.

MS received 14 October 2008; revised 18 May 2009; accepted 19 May 2009 